\title{
A new name and seventeen new combinations in the Magnolia (Magnoliaceae) of China and Vietnam
}

\author{
Chris Callaghan ${ }^{*}$ and Siak-Khoon (SK) Png
}

\begin{abstract}
Background: A new name is proposed and seventeen new combinations are made as a result of the previous reduction of the remaining genera of subfamily Magnolioideae (Magnoliaceae) into the genus Magnolia.

Results: The replacement name Magnolia fansipanensis is proposed for Manglietia crassifolia Q. N. Vu et al., since its transfer to Magnolia would create an illegitimate later homonym of the fossil name M. crassifolia Göpp. A further 17 new combinations are made to transfer the following taxa to Magnolia: Manglietia guangzhouensis A. Q. Dong et al., M. kaifui Q. W. Zeng \& X. M. Hu, M. lawii N. H. Xia \& W. F. Liao, plus Michelia concinna H. Jiang \& E. D. Liu, M. jianfenglingensis G. A. Fu \& K. Pan, M. viridipetala Y. W. Law et al., M. wuzhishangensis G. A. Fu \& K. Pan, M. xianianhei Q. N. Vu and Yulania carnosa D. L. Fu \& D. L. Zhang, Y. cuneatofolia T. B. Chao (probably Zhao) et al., Y. dabieshanensis T. B. Zhao et al., Y. dimorpha T. B. Zhao \& Z. X. Chen, Y. fragarigynandria T. B. Zhao et al., Y. shirenshanensis D. L. Fu \& T. B. Zhao, Y. shizhenii D. L. Fu \& F. W. Li, Y. verrucata D. L. Fu et al. and Y. xinyangensis T. B. Zhao et al.
\end{abstract}

Conclusions: The transfer of the above taxa to Magnolia is necessary following the present almost universal recognition of Magnolioideae as one of two monogeneric subfamilies within Magnoliaceae.

Keywords: Magnolia fansipanensis; Magnolioideae; Manglietia; Michelia; new combinations; new name; Yulania

\section{Background}

The authors of a number of new magnoliaceous taxa from China and Vietnam described in recent years have followed the treatment of Magnoliaceae in the Flora of China (Xia et al. 2008), where Manglietia and Michelia are retained and Yulania is reinstated as segregate genera in subfamily Magnolioideae. In the present account, 17 new combinations are made and one new name is proposed in accordance with the relegation of all remaining genera of subfamily Magnolioideae into Magnolia by Figlar (2000), Figlar and Nooteboom (2004).

\section{Methods}

The new combinations and new name proposed in this paper are made in compliance with the rules and recommendations of the 2011 International Code of

* Correspondence: callaghan_aba@yahoo.com.au

Australian Bicentennial Arboretum, P.O. Box 88, Penshurst, NSW 2222, Australia
Nomenclature for algae, fungi and plants (ICN), known as The Melbourne Code (McNeill, Turland et al. 2012), in particular ICN Article 41 and Recommendation 41A in respect of new combinations and replacement names.

\section{Results and discussion}

The problematic past 150 year history of the family Magnoliaceae is too lengthy to detail here. Suffice it to say that with the sinking of all remaining genera of the previously contentious subfamily Magnolioideae into Magnolia, that there is at last relative stability in this subfamily that would appear will require minimal refinement or disruptive changes in the future. For the most comprehensive accounts of past changes ultimately leading to almost universal acceptance of the family Magnoliaceae as consisting of two subfamilies, Liriodendroideae represented only by Liriodendron, and the now monogeneric Magnolioideae comprising all its former genera, including Michelia and Manglietia, now under Magnolia, the reader is referred to the historical records provided by Richard (Dick) Figlar,

\section{Springer}


the former president of Magnolia Society International, that have appeared in various publications since the first International Symposium on Family Magnoliaceae (Figlar 2000 and particularly Figlar 2006, Figlar 2009, Figlar 2012).

As Figlar makes clear in his later papers, the advent of molecular DNA sequencing data, in conjunction with on-going morphological study, especially of living plants, has allowed critical analysis of the taxonomic relationships of subfamily Magnolioideae taxa during the last ca. 20 years, that has surpassed any understanding of the classification of the subfamily that had accrued in the preceding more than a century of mainly morphological research.

The findings of the studies of numerous researchers that are most pertinent to the present paper (DNA analysis by Azuma et al. 1999, 2000, 2001, Kim et al. 2001, Nie et al. 2008, Wang et al. 2006, plus others; morphological studies by Figlar 2000, Figlar and Nooteboom 2004), have provided convincing evidence that both Manglietia and Michelia are nested within the genus Magnolia, the former under Subgenus Magnolia Section Manglietia and the latter under Subgenus Yulania Section Michelia, Subsection Michelia.

In accordance with the above findings, a number of new combinations are made here, representing three species of Manglietia, five species of Michelia and nine species of Yulania named and described between 2008 and 2012 that are now transferred to Magnolia. Also, since its epithet in Magnolia is unavailable, Manglietia crassifolia, named in 2011, is renamed as Magnolia fansipanensis to reflect its occurrence on the north-eastern slopes of Mount Fansipan, the 'roof of Indo-China'.

Magnolia carnosa (D. L. Fu E D. L. Zhang) C. B. Callaghan \& SK Png comb. nov.

Basionym: Yulania carnosa D. L. Fu \& D. L. Zhang. In: D.L. Fu, D. L. Zhang, L. F. Wen, et al., Bull. Bot. Res. 30(4): 385, fig. 1 (2010).

TYPE: China, Sichuan, Beichuan County, alt. 1200 m., secondary forests, 14 Mar. 2001, D. L. Fu 200103141 (holotype: CAF).

Magnolia concinna (H. Jiang $\mathcal{E} E$.D. Liu) C. B. Callaghan \& SK Png comb. nov.

Basionym: Michelia concinna H. Jiang \& E. D. Liu. In: Annales Botanici Fennici 45(4): 290, fig. 1 (2008).

TYPE: China, Yunnan, Kunming Arboretum, alt. 1990 m, 22 March 2006, H. Jiang 03942 (holotype: KUN; isotypes: H, PE, YAF). [transplanted from an unknown habitat in SE Yunnan].

Note - Magnolia concinna Y. W. Law \& R. Z. Zhou. In: Liu et al. (2004) 44, is an invalid name for a different taxon, as no Latin description or diagnosis was given (ICN Art. 39.1) and no type was indicated. (ICN Art. 40.1).
Magnolia cuneatifolia (T. B. Chao, Z. X. Chen E D. L. Fu) C. B. Callaghan E SK Png comb. nov.

Basionym: Yulania cuneatofolia T. B. Chao, Z. X. Chen \& D. L. Fu. In: D. L. Fu et al. Bull. Bot. Res. 30(6): 643, fig. 2 (2010).

TYPE: China, Henan, Zhengzhou, 24 Mar. 2005, T. B. Zhao et al. 200503241 (holotype: HEAC; isotype: CAF); ibid. 18 Sept. 2005, T. B. Zhao \& Z. X. Chen (CAF).

Note 1 - There is an apparent orthographical error in the original epithet which should be 'cuneatifolia', as this Latin compound should be formed by the connecting vowel - $i$-. (ICN Art. 60.1 - "the original spelling of a name or epithet is to be retained, except for the correction of typographical or orthographical errors"). Note 2 - There is a probable error in the lead author's name which may be T. B. Zhao as for the specimen collector's name. Note 3 While the paper in which Yulania cuneatofolia is named as a new species is titled "Two new species of Yulania Spach from Hubei Province", this species is only noted in that paper as occurring in Henan Province, as for the type specimens above.

Magnolia dabieshanensis (T. B. Zhao, Z. X. Chen $\mathcal{E}$ H. T. Dai) C. B. Callaghan E SK Png comb. nov.

Basionym: Yulania dabieshanensisT. B. Zhao, Z. X. Chen \& H. T. Dai. In: H. T. Dai, D. W. Zhao, J. Li, et al., J. Xinyang Normal Uni. (Nat. Sci. Ed.) 25(3): 334, fig. 2 (2012).

TYPE: China, Henan, Jigongshan, 24 Feb. 1999, Tianbang Zhao 992241 (holotype: HEAC, fl.); ibid. 18 July 1999, 997181 (HEAC, fol.).

Note - The type collection was made on Mount Jigongshan in the Dabieshan mountain range straddling the border of Henan and Hubei Provinces, hence the specific epithet.

Magnolia dimorpha (T. B. Zhao \& Z. X. Chen) C. B. Callaghan \& SK Png comb. nov.

Basionym: Yulania dimorpha T. B. Zhao \& Z. X. Chen. In: H. T. Dai, J. Li, D. L. Fu, et al., J. Xinyang Normal Uni. (Nat. Sci. Ed.) 25(4): 483, fig. 1 (2012).

TYPE: China, Henan, Xinyang Xian, Mt. Dabieshan, 25 April, 1994, T. B. Zhao et al. 944251 (holotype: HEAC).

Magnolia fansipanensis C. B. Callaghan E SK Png nom. nov.

Replaced synonym: Manglietia crassifolia Q. N. Vu, N. H. Xia \& Y. K. Sima. In: Novon 21(3): 375, fig. 1 (2011), non Magnolia crassifolia Göppert (1852) 277 [fossil taxon].

TYPE: Vietnam, Lao Cai Province, Sa Pa District, Hoang Lien National Park, alt. 1890 m, 18 Dec. 2009, V. Q. Nam 181209.3 (holotype: VNF; isotype: IBSC).

Note 1 - The replacement name Magnolia fansipanensis is proposed for Manglietia crassifolia because its transfer to Magnolia would create a later homonym to the fossil taxon Magnolia crassifolia Göpp. (ICN Art. 
53.1, also ICN Art. 11.8 Note 5 - "in accordance with Art. 53, later homonyms are illegitimate whether the type is fossil or non-fossil"). Note 2 - The species is renamed after Vietnam's highest mountain, Mount Fansipan, which the present authors climbed in 2007 (Callaghan 2008), and 2010, and on whose northeastern slopes the species occurs in small numbers between 1800-2000 m. Note 3 - As the lead author and the collector are the same person ( $\mathrm{Vu}$ Quang Nam), there would appear to be an irregular citation in the name of this collector of the nomenclatural type and its duplicate. While the use of a person's given name is customary as a primary form of address in Vietnam, its use in an international scientific journal is potentially confusing.

Magnolia fragarigynandria (T. B. Zhao, Z. X. Chen $\mathcal{E}$ H. T. Dai) C. B. Callaghan E SK Png comb. nov.

Basionym: Yulania fragarigynandria T. B. Zhao, Z. X. Chen \& H. T. Dai. In: H. T. Dai, D. W. Zhao, J. Li et al., J. Xinyang Normal Uni. (Nat. Sci. Ed.) 25(3): 334, fig. 1 (2012).

TYPE: China, Henan, Changyuan County, Tian-ban Zhao et al. 200303115 (holotype: HEAC, fl.).

Magnolia guangzhouensis (A. Q. Dong, Q. W. Zeng $\mathcal{E}$ F. W. Xing) C. B. Callaghan E SK Png comb. nov.

Basionym: Manglietia guangzhouensis A. Q. Dong, Q. W. Zeng \& F. W. Xing. In: A. Q. Dong et al., Nordic J. Bot. 27: 339 (2009).

TYPE: China, Guangdong, Guangzhou, Conghua, Mount Dalingshan, in evergreen broad-leaved forests, ca. $750 \mathrm{~m}$. 14 June, 2007, An-qiang Dong 1184 (holotype: IBSC).

Magnolia jianfenglingensis (G. A. Fu E K. Pan) C. B. Callaghan \& SK Png comb. nov.

Basionym: Michelia jianfenglingensis G. A. Fu \& K. Pan. In: Bull. Bot. Res., Harbin 32(3): 257, fig. 1 (2012).

TYPE: China, Hainan Island, Ledong County, Jianfengling, ca. 800 m. 22 August, 1995, Guo-ai Fu 11338 (holotype: HFB, fl.); ibid. Guo-ai Fu 8144 (HFB, fr.).

Magnolia kaifui (Q. W. Zeng \& X. M. Hu) C. B. Callaghan \& SK Png comb. nov.

Basionym: Manglietia kaifui Q. W. Zeng \& X. M. Hu. In: X. M. Hu et al., Pakistan J. Bot. 43(5): 2270, figs. 1, 2 (2011).

TYPE: China, Yunnan, Luchun County, Mount Huanglianshan, monsoon evergreen forests, alt.13002000 m, 12 May 2004, Qing-Wen Zeng 88 (holotype and isotype: IBSC).

Magnolia lawii (N. H. Xia \& W. F. Liao) C. B. Callaghan \& SK Png comb. nov.

Basionym: Manglietia lawii N. H. Xia \& W. F. Liao. In: Liao and Xia, Nordic J. Bot. 27(1): 1, ill. (2009).

TYPE: China, Yunnan, Maguan County, mixed woods of Fagaceae and Lauraceae, alt.1500-2000 m. 16 May 1982, Y. H. Liu 7032 (holotype: IBSC).
Magnolia shirenshanensis (D. L. Fu E T. B. Zhao) C. B. Callaghan \& SK Png comb. nov.

Basionym: Yulania shirenshanensis D. L. Fu \& T. B. Zhao. In: D. X. Zhao, T. B. Zhao \& D. L. Fu, 2011 Int'l Conf. Agricult. Nat. Res. Eng.: Adv. Biomed. Eng. 3-5: 91, fig. 1 (2011).

TYPE: China, Henan, Lushan County, Shirenshan, 26 Mar. 2000, T. B. Zhao et al. 200003261 (holotype: HNAC, fl.); ibid. 25 Aug. 2000, D. L. Fu E T. B. Zhao 200008251 (HNAC, fol., br.).

Magnolia shizhenii (D. L. Fu \& F. W. Li) C. B. Callaghan \& SK Png comb. nov.

Basionym: Yulania shizhenii D. L. Fu \& F. W. Li. In: D. L. Fu, D. L. Zhang, L. F. Wen, et al., Bull. Bot. Res. 30 (4): 387, fig. 2 (2010).

TYPE: China, Sichuan, Chengdu City, 16 Mar. 2001, D. L. Fu 200103161 (holotype: CAF, fl., juv. fol.); ibid. 11 Sept. 2000, D. L. Fu 200009112 (CAF, br., fol.).

Magnolia verrucata $(D . L . F u, T . B$. Zhao \& S. S. Chen) C. B. Callaghan E SK Png comb. nov.

Basionym: Yulania verrucata D. L. Fu, T. B. Zhao \& S. S. Chen. In: Bull. Bot. Res. 30(6): 641, fig. 1 (2010).

TYPE: China, Hubei, Wuhan, 22 June 2001, D. L. Fu 2001062201 (holotype: CAF); ibid. 15 April 2000, T. B. Zhao E D. L. Fu 20004151 (CAF).

Magnolia viridipetala (Y. W. Law, R. Z. Zhou \& Q. F. Yi) C. B. Callaghan \& SK Png comb. nov.

Basionym: Michelia viridipetala Y. W. Law, R. Z. Zhou \& Q. F. Yi. In: Q. F.Yi et al., Nordic J. Bot. 26(5-6): 338, figs 1, 2 (2008).

TYPE: China, Yunnan, Fadou Xiang, Xichou County, evergreen broad-leaved forests, 1500 m. 20 March 2001, Ren-Zhang Zhou 20012 (holotype: IBSC).

Note - Michelia virensipetala Y. W. Law \& R. Z. Zhou. In: Liu Y. H. et al. (2004): 322, is an invalid name for the same taxon, as no Latin description or diagnosis was given (ICN Art. 39.1) and no type was indicated. (ICN Art. 40.1).

Magnolia wuzhishangensis (G. A. Fu E K. Pan) C. B. Callaghan \& SK Png comb. nov.

Basionym: Michelia wuzhishangensis G. A. Fu \& K. Pan. In: Bull. Bot. Res., Harbin 32(3): 258, fig. 2 (2012).

TYPE: China, Hainan Island, Chiunchun County, Limushang, 1300 m. 12 Apr. 1980, Guo-ai Fu 1713 (holotype: HFB, fl.); ibid. Guo-ai Fu 0892 (HFB, fr.).

Magnolia xianianhei $(Q . N . V u)$ C. B. Callaghan $\mathcal{E}$ SK Png comb. nov.

Basionym: Michelia xianianhei Q. N. Vu. In: Nordic J. of Bot. 30(5): 575, figs. 1, 2 (2012).

TYPE: Vietnam, Dien Bien Province, Dien Bien District, Muong Phang Municipality, Vo Nguyen Giap Historical Vestige, 1004 m. 31 Dec. 2010, Nam 311210.2 (holotype: VNF; isotype: IBSC).

Note - There would appear to be an irregular citation in the name of the collector of the nomenclatural type 
and its duplicate, since the author and collector is the same person (Vu Quang Nam). While the use of a person's given name is customary as a primary form of address in Vietnam, its use in an international scientific journal is potentially confusing.

Magnolia xinyangensis (T. B. Zhao, Z. X. Chen \& H. T. Dai) C. B. Callaghan \& SK Png comb. nov.

Basionym: Yulania xinyangensis T. B. Zhao, Z. X. Chen \& H. T. Dai. In: H. T. Dai, J. Li, D. L. Fu, et al., J. Xinyang Normal Uni. (Nat. Sci. Ed.) 25(4): 485, fig. 2 (2012).

TYPE: China, Henan, Xinyang Xian, Mt. Dabieshan, 25 March 2000, T. B. Zhao et al. 200003251 (holotype: HNAC); ibid. 5 Oct. 1999, T. B. Zhao \& D. L. Fu 199910051 (fol., Yulania- alabastrum).

\section{Conclusions}

The transfer of the above eighteen taxa to Magnolia is necessary following the present near universal acceptance that Magnolioideae is one of two monogeneric subfamilies within Magnoliaceae and the fact that the majority of resulting new combinations and names arising from the relegation of Manglietia and Michelia into Magnolia have previously been made by various authors such as Figlar (2000) for the majority of Michelia species, Kumar (2006) for the majority of Manglietia species, with Sima (2001) transferring some further Michelia species and Nooteboom (in Xia et al. 2008:49-50) transferring a number of species from both genera.

\section{Competing interests}

The authors declare that they have no competing interests.

\section{Authors' contributions}

CC conceived of the paper. Both CC \& SKP participated in the research, acquisition of data and drafting of the manuscript. Both authors read and approved the original manuscript before submission to Botanical Studies on 6 June 2013 and then to the journal's Springer website on 30 June 2013. A revised manuscript was submitted to Springer on 14 August 2013 to include a necessary replacement name and a number of additional new combinations. Other matters dealt with in the original manuscript were withdrawn following peer review pending resolution of some unresolved issues now intended as the subject of a future paper. Both authors read and approved the final manuscript.

\section{Acknowledgements}

The authors wish to record their appreciation and thanks to Miguel Garcia, Research Librarian at the Royal Botanic Gardens, Sydney, Australia; Dr. Roger Spencer, Horticultural Botanist, and Sally Stewart, Librarian, both at the Royal Botanical Gardens, Melbourne, Australia; Frances Smith, Librarian at the Australian Museum, Sydney, Australia; Dr. Stephen Spongberg at Polly Hill Arboretum, USA; Prof. Ma Jinshuang, Chenshan Plant Science Research Centre, CAS, Shanghai, China; Dr. Shui Yu-min at Kunming Institute of Botany, CAS, Kunming, China; Prof. Wang Yin-Zheng, Institute of Botany, CAS, Beijing, China, and to Dr. Yang Qin-Er of the Key Laboratory of Plant Resources Conservation and Sustainable Utilization, South China Botanical Garden, CAS, Guangzhou, China, for assisting with our various enquiries. Richard Figlar, former President of Magnolia Society International, USA, earns our gratitude for providing his papers not readily available in Australia. Andy Ng in Sydney, Australia, is thanked for his translating skills. Two anonymous reviewers are thanked for their comments on the manuscript.
Received: 1 July 2013 Accepted: 25 October 2013

Published: 4 November 2013

\section{References}

Azuma H, Thien LB, Kawano S (1999) Molecular phylogeny of Magnolia (Magnoliaceae) inferred from cpDNA sequences and evolutionary divergence of floral scents. J Plant Res 112:291-306

Azuma H, Thien LB, Kawano S (2000) Molecular phylogeny of Magnolia based on chloroplast DNA sequence data and floral scent chemistry, pp 219-227. In: Liu YH, Fan HM, Chen ZY, Wu QG, Zeng QW (eds) Proceedings of the International Symposium on the Family Magnoliaceae, Hangzhou, China, May 1998. Science Press, Beijing

Azuma H, Garcia-Franco JG, Rico-Gray V, Thien LB (2001) Molecular phylogeny of the Magnoliaceae: The biogeography of tropical and temperate disjunctions. Am J Bot 88(12):2275-2285

Callaghan C (2008) Mount Fansipan, northern Vietnam. Int Dendrol Soc Yearbook 2007:162-169

Dai HT, Fu DL, et al. (2012) Two new species of Yulania Spach from Henan. Supplement of Iconographia Lignosorum Jigongshanicorum from Henan (II) [Supplement of Woody Illustrations of Jigongshan, Henan (II)]. J Xinyang Normal Uni (Nat Sci Ed) 25 No 109(4):482-485, 489 (in Chinese) DOI: 10.3969/j.issn. 1003-0972.2012.04.015

Dai HT, Zhao DW, Li J, et al. (2012) Two new species of Yulania Spach from Henan Province. J Xinyang Normal Uni (Nat Sci Ed) 25 No 108(3):333-335. (in Chinese) DOI: 10.3969/j. issn. 1003-0972.2012.03.013

Dong AQ, Zeng QW, Fu L, Xing FW (2009) Manglietia guangzhouensis sp. nov. (Magnoliaceae) from Guangdong. Nordic J Bot 27(4):339-343

Figlar D (2009) The sinking of Michelia and Manglietia into Magnolia. The Plantsman June 2009:118-123

Figlar RB (2000) Proleptic branch initiation in Michelia and Magnolia subgenus Yulania provides basis for combinations in subfamily Magnolioideae, pp 14 25. In: Liu YH, Fan HM, Chen ZY, Wu QG, Zeng QW (eds) Proceedings of the International Symposium on the Family Magnoliaceae, Hangzhou, China, May 1998. Science Press, Beijing

Figlar RB (2006) A new classification for Magnolia. Taxonomy Topics. Rhododendrons, with Camellias and Magnolias, 2006, pp 69-82

Figlar RB (2012) Turning points in the taxonomic history of Magnolioideae - from Baillon to Dandy to DNA, pp 47-54. In: Xia NH, Zeng QW, Xu FX, Wu QG (eds) Proceedings of the Second International Symposium on the Family Magnoliaceae, Guangzhou, China, May 2009. Huazhong University of Science and Technology Press, Wuhan

Figlar RB, Nooteboom HP (2004) Notes on Magnoliaceae IV. Blumea 49:87-100

Fu DL, Zhang DL, Wen LF, et al. (2010) Two new species of Yulania Spach from Sichuan Province of China. Bull Bot Res 30(4):385-389 (in Chinese)

Fu DL, Zhao TB, Chen ZX, Chen SS (2010) Two new species of Yulania Spach from Hubei Province of China. Bull Bot Res 30(6):641-644 (in Chinese)

Fu GA, Pan K (2012) Two new species of the genus Michelia (Magnoliaceae) from Hainan Island. Bull Bot Res Harbin 32(3):257-259 (in Chinese)

Göppert RJ (1852) Beitrage zur Tertiärflora Schlesien's. Palaeontogr B 2:257-285. pls. 33-38

Hu XM, Zeng QW, Fu L, Xing FW (2011) Manglietia kaifui - a new species from Yunnan, China. Pakistan J Bot 43(5):2269-2275

Jiang H, Liu ED (2008) Michelia concinna (Magnoliaceae), a new species from SE Yunnan, China. Ann Bot Fennici 45(4):290-292

Kim S, Park CW, Kim YD, Suh Y (2001) Phylogenetic relationships in family Magnoliaceae inferred from $n d h F$ sequences. Am J Bot 88:717-728

Kumar VS (2006) New combinations and new names in Asian Magnoliaceae. Kew Bulletin 61(2):183-186

Liao WF, Xia NH (2009) Manglietia lawii sp. nov. from Yunnan, China. Nordic J Bot 27(1):1-3

Liu YH, et al. (2004) Magnolias of China. Baitong Group. Beijing Science \& Technology Press, Beijing (in Chinese and English)

McNeill J, Turland NJ, et al. (2012) International Code of Nomenclature for algae, fungi, and plants (Melbourne Code). Regnum Vegetabile 154. Koeltz Scientific Books, Koenigstein. ICN available online at: www.iapt-taxon.org/nomen/ [English language version - accessed 28 April 2013]

Nie ZL, et al. (2008) Phylogenetic and biogeographic complexity of Magnoliaceae in the Northern Hemisphere inferred from three nuclear data sets. Mol Phylogen Evol 48:1027-1040

Sima YK (2001) Some notes on Magnolia subgenus Michelia from China. Yunnan Forest Sci Tech 2:29-35 (in Chinese, English abstract p 40) 
Vu QN, Xia NH, Sima YK (2011) Manglietia crassifolia (Magnoliaceae), a new species from Vietnam. Novon 21(3):375-379

Vu QN (2012) Michelia xianianhei sp. nov. (Magnoliaceae) from northern Vietnam. Nordic J Bot 30(5):575-577

Wang YL, Li Y, Zhang SZ, Yu ZS (2006) The utility of matK gene in the phylogenetic analysis of the genus Magnolia. Acta Phytotax Sin 44(2):135-147

Xia NH, Liu YH (Law YW), Nooteboom HP (2008) Magnoliaceae, pp 48-91. In: Wu ZY, Raven PH, Hong DY (eds) Flora of China, vol 7. Science Press, Beijing and Missouri Botanical Garden Press, St. Louis

Yi QF, Zhou RZ, Zeng QW, Xing FW (2008) Michelia viridipetala sp. nov. (Magnoliaceae) from Yunnan, China. Nordic J Bot 26(5-6):338-343

Zhao DX, Zhao TB, Fu DL (2011) A new species of Yulania Spach and chemical components of Xinyi essential oil of the new species. 2011 Int'l Conf Agric Nat Res Eng: Adv Biomed Eng 3-5:91-94

doi:10.1186/1999-3110-54-53

Cite this article as: Callaghan and Png: A new name and seventeen new combinations in the Magnolia (Magnoliaceae) of China and Vietnam. Botanical Studies 2013 54:53.

\section{Submit your manuscript to a SpringerOpen ${ }^{\circ}$} journal and benefit from:

- Convenient online submission

- Rigorous peer review

- Immediate publication on acceptance

- Open access: articles freely available online

- High visibility within the field

- Retaining the copyright to your article

Submit your next manuscript at $\boldsymbol{\wedge}$ springeropen.com 